\title{
Efficacy of melatonin supplementation in the treatment of periodontitis: a systematic review and meta-analysis
}

\section{Yuexiang Zhen}

Chongqing Medical University Stomatology College: Stomatological Hospital of Chongqing Medical University https://orcid.org/0000-0002-2105-3158

Hui Yue

Chongqing Medical University

\section{Yiting Xiao}

Chongqing Medical University

Qin Liu

Chongqing University of Medical Science: Chongqing Medical University

Meilin Zhao ( $\nabla$ zhaomeilin@hospital.cqmu.edu.cn )

Chongqing Medical University Stomatology College: Stomatological Hospital of Chongqing Medical University

\section{Research}

Keywords: Periodontitis, Melatonin, Nonsurgical periodontal therapy, Meta-analysis

Posted Date: April 1st, 2021

DOI: https://doi.org/10.21203/rs.3.rs-376485/v1

License: () (1) This work is licensed under a Creative Commons Attribution 4.0 International License. Read Full License 


\section{Abstract}

Background: The aim of this systematic review and meta-analysis was to analyze the additive effects of the melatonin supplementation with nonsurgical periodontal therapy (NSPT) on periodontal status in patients affected by chronic periodontitis.

Methods: In December 2020, We searched PubMed, EMBASE, Web of Science, CENTRAL databases and Google Scholar databases. Four RCTs were recruited with the same inclusion criteria. PD and CAL were the primary outcome measures. Subgroup analyses were performed according to health statuses and follow-up times, and Cochran's $Q$ and I-square $\left(I^{2}\right)$ tests were used to assess heterogeneity.

Results: This review included four RCTs. Four studies reported probing depth (PD) and 3 studies reported clinical attachment loss (CAL). Compared with the placebo groups, the melatonin groups showed a significant reduction in PD (weighted mean difference [WMD], $-1.01 ; 95 \%$ confidence intervals [CI], -1.67 to $-0.35 ; \mathrm{I}^{2}=76 \%$ ) and CAL (WMD, $-1.08 ; 95 \% \mathrm{Cl}:-1.36$ to $-0.79, \mathrm{I}^{2}=$ $0 \%)$. Subgroup analyses revealed that the use of systemic melatonin + NSPT significantly reduced PD and CAL at the 2-, 3-, and 6-month follow-ups compared to NSPT alone, and stronger treatment effects of reducing PD were observed at shorter followups than at longer follow-ups when adjunctive systemic melatonin was used.

\section{Conclusions:}

Melatonin supplementation in adjunct with nonsurgical periodontal therapy can moderately improve the efficacy of NSPT in reducing PD and greater CAL gain in patients with periodontitis. With the limited evidence available, it is evident that additional good quality RCTs are required to demonstrate additional beneficial effects of oral melatonin supplementation on periodontal clinical parameters after NSPT.

\section{Background}

Chronic periodontitis (CP) is an inflammatory disease mainly caused by subgingival microbial plaque and characterized by the destruction of tooth-supporting tissues [1, 2]. The damage to periodontal tissue is related to the production of certain harmful substances, including pro-inflammatory cytokines, free radicals, reactive oxygen species and reactive nitrogen, some of which are directly produced by periodontal bacteria and others of which are produced by the host immune response to dysbiotic microbial presence $[3,4]$. The release of these products is largely sustained, driving the progressive loss of connective tissue attachment and alveolar bone and even tooth loss if not treated promptly [3,5]. Nonsurgical periodontal therapy (NSPT), a standard treatment for periodontitis, mainly includes professional oral hygiene instructions $(\mathrm{OHI})$ and full-mouth subgingival scaling and root planing (SRP), which mechanically removes dental plaque and calculus on the root surface. However, the limitations of inaccessible periodontal defects [6] and poor host inflammatory-immune response [7] can influence the effectiveness of periodontal healing. Although NSPT can successfully suppress the progression of inflammation and prevent progressive bone loss in some cases, the ability of the periodontium to their return to original form and function is still limited. Regarding these issues, periodontal clinicians have considered the use of host modulatory agents as adjuvant therapies to modulate the host immune response and boost the regeneration of periodontal tissue $[8,9]$. Host modulatory agents can affect the host immune response through different pharmacological mechanisms [4, 9]. For example, tetracycline antibiotics inhibit the synthesis of matrix metalloproteinase [10], nonsteroidal anti-inflammatory drugs inhibit the release of pro-inflammatory cytokines and prostaglandins [11]. and bone-sparing agents block the expression of osteoclasts [12, 13]. However, these drugs may cause resistance, opportunistic infections, and other side effects [14, 15].

Melatonin (N-acetyl-5-methoxy-tryptamine) is an important hormone that is mainly secreted by the pineal gland and is associated with the circadian rhythm $[16,17]$. Melatonin can be correlated with the development and severity of periodontitis [18]. Previous studies have shown that the level of melatonin in plasma and saliva is significantly decreased in patients with periodontitis compared to healthy patients $[19,20]$. Melatonin can be used as a dietary supplement or as a prescription drug in different countries [4]. Melatonin possesses a wide spectrum of essential properties, such as anti-inflammatory, 
immunomodulatory $[21,22]$ and antioxidant effects [22, 23], free radical scavenging; bone metabolism regulation [24], As such, melatonin could be used as a novel host modulatory agent to modulate the host response in patients with destructive periodontitis [25]. Therefore, research on melatonin supplementation after NSPT in the treatment of periodontal disease has attracted the attention of clinicians.

Currently, some publications have reported that systemic melatonin after NSPT in patients with periodontitis has advantages in reducing probing depth (PD) and clinical attachment loss (CAL) compared with NSPT alone [26, 27]. However, other studies have noted no significant difference in the results of the clinical outcomes for NSPT combined with melatonin supplementation compared with NSPT alone [28]. This uncertain evidence is not conducive to the clinical application or promotion of melatonin in patients with periodontitis.

To the best of our knowledge, there is no systematic review or meta-analysis of RCTs evaluating the effects of NSPT combined with melatonin on clinical outcomes in patients with periodontitis. Therefore, the primary purpose of this study was to summarize the available evidence and determine the effects of melatonin supplementation in combination with NSPT on clinical outcomes in patients with periodontitis.

\section{Methods}

\section{Guidelines}

We conducted this study following the guidelines of the Transparent Reporting of Systematic Reviews and Meta-Analyses (PRISMA) statement [29].

\section{Search plan}

We comprehensively searched the PubMed, EMBASE and the Cochrane Central Register of Controlled Trials (CENTRAL) databases for relevant articles published before April 2020 in the English language. We used the following terms (MeSH) and free text keywords: population ["periodontal disease" OR "chronic periodontitis"], intervention ["periodontal therapy" OR "periodontal debridement" OR "nonsurgical periodontal debridement" AND "melatonin"]. We also manually checked the reference lists of selected studies to identify any possible eligible citations. The detailed search strategy is illustrated in supplementary Table S1.

Two investigators (YX.Z and H.Y.) independently conducted the study screening process. We deleted duplicate publications and excluded those that were ineligible by reviewing titles and abstracts. Finally, we read the full text carefully to identify eligible studies. Any disagreement during the study selection process was settled by discussion. To identify additional publications, we manually searched the reference lists of the included studies. We did not contact the original authors for further information.

\section{Inclusion and exclusion criteria}

We included RCTs with no minimum duration that evaluated the effects of systemic melatonin adjunctive to NSPT compared with NSPT plus a placebo or alone in patients with periodontitis. The primary outcome measures were PD and CAL. The secondary outcome measure was the occurrence of adverse effects related to melatonin administration. We excluded case reports, animal studies, and studies that used local melatonin delivery adjunctive to NSPT. In addition, we also excluded studies that used systemic melatonin with other concomitant oral medications.

\section{Data extraction}

Two investigators (ML.Z. and YX.Z.) independently collected and extracted the following data: first author's name, publication date, study location, study design, participants' characteristics, total sample size and dropouts, intervention (the treatment conditions of NSPT; dose, usage of melatonin, and duration of treatment), type of systematic disease, periodontitis definition, study duration, outcome measures, and sponsor. Disagreements regarding extracted information between the two reviewers were settled by discussion.

\section{Quality assessment}


Two investigators (Q.L. and YT.X.) individually performed the quality assessment of included trials based on the Cochrane Collaboration's tool [30]. The third reviewer resolved any disagreements regarding the study quality assessment. The methodological quality included the following criteria: randomization generation, and allocation concealment; blinding of participants, personnel and examiners; outcome assessment; incomplete outcome data; selective outcome reporting; and other sources of bias. Overall, the risk of study bias was categorized as follows: 1) low risk of bias: there was a "low" risk answer for all domains; 2) moderate risk of bias: there was an "unclear" risk answer for one or more domains; 3) high risk of bias: there was a "high" risk answer for one or more domains.

\section{Statistical analysis}

Two investigators (Q.L. and H.Y.) determined the effects of NSPT plus melatonin supplementation and NSPT alone on periodontal parameter variables in patients with CP. Trial outcome data were pooled into weighted mean differences (WMDs) with $95 \%$ confidence intervals (Cls) using RevMan 5.3 software (Cochrane Collaboration). Heterogeneity among studies was estimated using the Cochran (Q) and $\mathrm{l}$-square tests $\left(\mathrm{I}^{2}\right) . P<0.1$ and $\mathrm{I}^{2}>50 \%$ indicated substantial heterogeneity. Otherwise, when $P \geq 0.1$ and $I^{2} \leq 50 \%$, heterogeneity was acceptable [30]. We used a random-effects model for our meta-analysis. Owing to the small number of included studies, the assessment of publication bias by using a funnel plot was not evaluated [30].

\section{Results}

\section{Literature search}

A total of 151 potentially eligible publications were identified from the electronic databases search. Ninety-eight studies were screened after duplicate removal. The full texts of 10 studies were retrieved according to the established inclusion criteria. Ultimately, four studies [25-28] were finally considered eligible for inclusion in this review (Fig. 1).

\section{Characteristics of the included studies}

The detailed information of the included studies for the intervention and placebo groups is summarized in Table 1, Table 2 and Table S2. Overall, four included RCTs [25-28] reported 198 patients who presented mild to severe CP. The investigators of four studies identified CP as involving at least one site with a PD of 4 millimetres or greater. The investigators of three studies provided the CAL threshold value in the definition of CP [28], while one study did not report CAL values or bone loss [28]. The investigators of two studies $[25,28]$ recruited systematically healthy patients with CP. The remaining two studies recruited patients with comorbidities, one study recruited patients with primary insomnia [27], and the other study recruited patients with type 2 diabetes mellitus (DM) [26]. The dose of melatonin varied from 1 to $10 \mathrm{mg} / \mathrm{day}$. The participants of two included studies received systemic melatonin for two months [26-28], while the participants of the other two studies received systemic melatonin for one month [25]. Tinto and colleagues [25] reported that SRP was performed in one-session in the full mouth under local anaesthesia and it took nearly 45 minutes per quadrant. El-Sharkawy and colleagues [27] only reported SRP over two separate visits, but the investigators of three studies did not define SRP in detail [26-28]. The participants of 2 included studies did not receive local antimicrobials after SRP [26, 28], but El-Sharkawy [27] and Tinto [25] combined antimicrobial treatment with a $0.12 \%$ and $0.20 \%$ chlorhexidine rinse twice a day for two weeks for study participants after SRP, respectively. 
Table 1

Characteristics of the included studies

\begin{tabular}{|c|c|c|c|c|c|c|c|c|c|}
\hline $\begin{array}{l}\text { Author } \\
\text { year, } \\
\text { country }\end{array}$ & Country & $\begin{array}{l}\text { Study } \\
\text { design }\end{array}$ & $\begin{array}{l}\text { Sample } \\
\text { size (no. } \\
\text { dropouts) }\end{array}$ & $\begin{array}{l}\text { Mean } \\
\text { age } \\
\text { or } \\
\text { range } \\
\text { (y) }\end{array}$ & Smokers & $\begin{array}{l}\text { Other } \\
\text { systemic } \\
\text { condition }\end{array}$ & $\begin{array}{l}\text { Periodontitis } \\
\text { definition } \\
(\mathrm{mm}) / \text { clinical } \\
\text { examination }\end{array}$ & $\begin{array}{l}\text { Duration } \\
\text { (mo) }\end{array}$ & Sponsor \\
\hline $\begin{array}{l}\text { Chitsazi } \\
\text { et al. } \\
2017 \text { [28], } \\
\text { Iran }\end{array}$ & Iran & $\begin{array}{l}\text { RCT } \\
\text { parallel } \\
\text { design }\end{array}$ & $60(0)$ & $\begin{array}{l}23- \\
65\end{array}$ & No & No & $\begin{array}{l}\text { Moderate to } \\
\text { severe } \mathrm{CP} \\
\mathrm{PD} \geq 5 \mathrm{UNC}- \\
15 \text { probe }\end{array}$ & 3,6 & $\begin{array}{l}\text { Tabriz } \\
\text { University } \\
\text { Dental and } \\
\text { Periodontal } \\
\text { Research } \\
\text { Center }\end{array}$ \\
\hline $\begin{array}{l}\text { El- } \\
\text { Sharkawy } \\
\text { et al. } \\
2019 \text { [27], } \\
\text { Egypt }\end{array}$ & Egypt & $\begin{array}{l}\text { RCT } \\
\text { parallel } \\
\text { design }\end{array}$ & $80(6)$ & $\begin{array}{l}38- \\
55\end{array}$ & No & $\begin{array}{l}\text { primary } \\
\text { insomnia }\end{array}$ & $\begin{array}{l}\geq 20 \text { teeth, } \\
\text { moderate to } \\
\text { severe } \mathrm{CP}, \\
\mathrm{PD} \geq 5 \text { and } \\
\text { radiographic } \\
\mathrm{CAL} \geq 4 \text { at } \\
\text { least three } \\
\text { sites in each } \\
\text { quadrant } \\
\text { Probe not } \\
\text { reported }\end{array}$ & 3,6 & No \\
\hline $\begin{array}{l}\text { Bazyar et } \\
\text { al. } \\
2018 \text { [26], } \\
\text { Iran }\end{array}$ & Iran & $\begin{array}{l}\text { RCT } \\
\text { parallel } \\
\text { design }\end{array}$ & $50(6)$ & $\begin{array}{l}\text { T: } \\
53.72 \\
\pm 6.68 \\
\text { C: } \\
51.45 \\
\pm 5.03\end{array}$ & No & $\begin{array}{l}\text { type } 2 \\
\text { Diabetes } \\
\text { mellitus }\end{array}$ & $\begin{array}{l}\text { Mild and } \\
\text { moderate } \mathrm{CP}, \\
\mathrm{PD} \geq 4 \text { and } \\
\mathrm{CAL}=1-4 \\
\text { UNC-15 } \\
\text { probe }\end{array}$ & 2 & No \\
\hline $\begin{array}{l}\text { Tinto et } \\
\text { al. } \\
2019 \text { [25], } \\
\text { Italy }\end{array}$ & Italy & $\begin{array}{l}\text { RCT } \\
\text { parallel } \\
\text { design }\end{array}$ & $20(0)$ & $\begin{array}{l}30- \\
70\end{array}$ & No & No & $\begin{array}{l}\text { Severe CP, } \\
\text { CAL } \geq 5 \text {, } \\
\geq 20 \text { teeth, } \\
\text { PD } \geq 6 \\
\begin{array}{l}\text { Probe not } \\
\text { reported }\end{array}\end{array}$ & 6 & $\begin{array}{l}\text { Periodontal } \\
\text { Unit of } \\
\text { Santa } \\
\text { Apollonia } \\
\text { Dental } \\
\text { Center }\end{array}$ \\
\hline
\end{tabular}


Table 2

Participants, interventions, outcomes and results

\begin{tabular}{|c|c|c|c|c|c|c|}
\hline \multirow{2}{*}{$\begin{array}{l}\text { Author, } \\
\text { year, } \\
\text { country }\end{array}$} & \multirow[t]{2}{*}{ Participants } & \multirow[t]{2}{*}{ Groups } & \multicolumn{2}{|l|}{ Interventions } & \multirow{2}{*}{$\begin{array}{l}\text { Outcome } \\
\text { variables/adverse } \\
\text { effects }\end{array}$} & \multirow[t]{2}{*}{ Results } \\
\hline & & & NSPT & $\begin{array}{l}\text { Drug usage and } \\
\text { dosage }\end{array}$ & & \\
\hline \multirow{4}{*}{$\begin{array}{l}\text { Chitsazi } \\
\text { et al. } \\
2017 \text { [28], } \\
\text { Iran }\end{array}$} & $\mathrm{T}: \mathrm{N}=40$ & \multirow{4}{*}{$\begin{array}{l}\text { T: NSPT } \\
+ \\
\text { melatonin } \\
\text { C: NSPT }\end{array}$} & \multirow[t]{4}{*}{$\mathrm{OHI}+\mathrm{SRP}$} & \multirow{4}{*}{$\begin{array}{l}2 \text { mg melatonin } \\
\text { a day for } 1 \mathrm{mo}\end{array}$} & $\mathrm{PD}, \mathrm{CAL}$ & \multirow{4}{*}{$\begin{array}{l}\text { T VS. C } \\
\text { in PD } \\
\text { and CAL } \\
\text { scores: } \mathrm{P} \\
>0.05\end{array}$} \\
\hline & $C: N=40$ & & & & None & \\
\hline & 31 females, & & & & & \\
\hline & 29 males & & & & & \\
\hline \multirow{4}{*}{$\begin{array}{l}\text { El- } \\
\text { Sharkawy } \\
\text { et al. } \\
2019 \text { [27], } \\
\text { Egypt }\end{array}$} & $\mathrm{T}: \mathrm{N}=38$ & \multirow{4}{*}{$\begin{array}{l}\text { T: NSPT } \\
+ \\
\text { melatonin } \\
\text { capsule } \\
\text { C: NSPT } \\
+ \text { Placebo }\end{array}$} & \multirow{4}{*}{$\begin{array}{l}\mathrm{OHI}+\text { two-session } \\
\mathrm{SRP}+0.12 \% \\
\text { chlorhexidine rinse } \\
\text { for } 2 \text { weeks }\end{array}$} & \multirow{4}{*}{$\begin{array}{l}10 \mathrm{mg} \\
\text { melatonin once } \\
\text { per day } 1 \text { hour } \\
\text { before bedtime } \\
\text { for } 2 \text { mo }\end{array}$} & CAL, PD & \multirow{4}{*}{$\begin{array}{l}\text { T VS. C } \\
\text { in PD } \\
\text { and CAL: } \\
P<0.01\end{array}$} \\
\hline & $C: N=36$ & & & & Cases of headache, & \\
\hline & 33 females, & & & & constipation, & \\
\hline & 41 males & & & & cramp $\leq 2$ & \\
\hline \multirow{4}{*}{$\begin{array}{l}\text { Bazyar et } \\
\text { al. } \\
2018 \text { [26], } \\
\text { Iran }\end{array}$} & $\mathrm{T}: \mathrm{N}=22$ & \multirow{4}{*}{$\begin{array}{l}\text { T: NSPT } \\
+ \\
\text { melatonin } \\
\text { tablets } \\
\text { C: NSPT } \\
+ \text { placebo }\end{array}$} & \multirow[t]{4}{*}{$\mathrm{OHI}+\mathrm{SRP}$} & \multirow{4}{*}{$\begin{array}{l}3 \text { mg melatonin } \\
\text { once a day } 1 \\
\text { hour before } \\
\text { bedtime for } 2 \\
\text { mo }\end{array}$} & PD, CAL & \multirow{4}{*}{$\begin{array}{l}\text { T VS. C } \\
\text { PD and } \\
\text { CAL } P< \\
0.01\end{array}$} \\
\hline & $\mathrm{C}: \mathrm{N}=22$ & & & & None & \\
\hline & 30 females, & & & & & \\
\hline & 14 males & & & & & \\
\hline \multirow{3}{*}{$\begin{array}{l}\text { Tinto et } \\
\text { al. } \\
2019 \text { [25], } \\
\text { Italy }\end{array}$} & $\mathrm{T}: \mathrm{N}=10$ & \multirow{2}{*}{$\begin{array}{l}\mathrm{T}: \mathrm{NSPT} \\
+ \\
\text { melatonin } \\
\text { tablets }\end{array}$} & \multirow{2}{*}{$\begin{array}{l}\mathrm{OHI}+\text { one-session } \\
\text { SRP (1 quadrant per } \\
45 \text { minutes with } \\
\text { local anesthesia) }\end{array}$} & \multirow{3}{*}{$\begin{array}{l}1 \mathrm{mg} \text { melatonin } \\
\text { once a day at } \\
\text { bedtime for } 1 \\
\text { mo }\end{array}$} & PD & \multirow{3}{*}{$\begin{array}{l}\text { T VS. C } \\
\text { in PD: } P \\
>0.05\end{array}$} \\
\hline & $\mathrm{C}: \mathrm{N}=10$ & & & & $\begin{array}{l}\text { T: } 20 \% \text { sleepiness and } \\
10 \% \text { headache }\end{array}$ & \\
\hline & 12 males & $\begin{array}{l}\text { C: NSPT } \\
\text { + placebo }\end{array}$ & $\begin{array}{l}+0.20 \% \\
\text { chlorhexidine rinse } \\
\text { for } 2 \text { weeks }\end{array}$ & & & \\
\hline
\end{tabular}

\section{Quality assessment of selected studies}

Of the four included RCTs, three had a low risk of bias [25-27], and one exhibited a moderate risk of bias [28]. The risk of bias quality assessments of the included RCTs is presented in Table 3. All included studies received a "yes" answer for aspects of randomized sequence generation, allocation concealment, blinding of participants and personnel, complete data, and other bias. The risk answer was assigned because the blinding of allocation for the participants was not described. Overall, the quality of studies was considered moderate in 1 RCT and high in 3 RCTs. 
Table 3

Risk of quality assessment of the selected studies

\begin{tabular}{|c|c|c|c|c|c|c|c|c|}
\hline $\begin{array}{l}\text { Author } \\
\text { year, } \\
\text { country }\end{array}$ & $\begin{array}{l}\text { Random } \\
\text { sequence } \\
\text { generation }\end{array}$ & $\begin{array}{l}\text { Allocation } \\
\text { concealment }\end{array}$ & $\begin{array}{l}\text { Blinding of } \\
\text { participants } \\
\text { and personnel }\end{array}$ & $\begin{array}{l}\text { Blinding } \\
\text { of } \\
\text { outcome }\end{array}$ & $\begin{array}{l}\text { Incomplete } \\
\text { outcome } \\
\text { data }\end{array}$ & $\begin{array}{l}\text { Selective } \\
\text { reporting }\end{array}$ & $\begin{array}{l}\text { Other } \\
\text { biases }\end{array}$ & $\begin{array}{l}\text { Overall } \\
\text { risk of } \\
\text { bias }\end{array}$ \\
\hline $\begin{array}{l}\text { Chitsazi et } \\
\text { al. } \\
2017 \text { [28], } \\
\text { Iran }\end{array}$ & low & unclear & low & low & low & low & low & moderate \\
\hline $\begin{array}{l}\text { El-Sharkawy } \\
\text { et al. } 2019 \\
\text { [27], Egypt }\end{array}$ & low & low & low & low & low & low & low & low \\
\hline $\begin{array}{l}\text { Bazyar et al. } \\
2018 \text { [26], } \\
\text { Iran }\end{array}$ & low & low & low & low & low & low & low & low \\
\hline $\begin{array}{l}\text { Tinto et al. } \\
2019 \text { [25], } \\
\text { Italy }\end{array}$ & low & low & low & low & low & low & low & low \\
\hline
\end{tabular}

\section{The primary outcomes}

The investigators of the four included studies reported PD [25-28] between baseline and follow-up visits, and the investigators of three studies reported CAL [26-28]. Overall, there were significant differences in reducing PD (WMD, $-1.01 ; 95 \% \mathrm{Cl},-1.67$ to $-0.35 ; I^{2}=76 \%$ ) and CAL (WMD, $-1.08 ; 95 \% \mathrm{Cl}:-1.36$ to $-0.79, \mathrm{I}^{2}=0 \%$ ), as presented in Fig. 2 and Fig. 3 . There was substantial heterogeneity in PD $\left(I^{2}=76 \%\right)$ among the studies.

\section{Secondary outcome measures}

One study [25] mentioned that, in the melatonin group, two patients reported sleepiness, and one patient reported headache. One trial [27] reported cases of headache, dizziness, nausea, and gastrointestinal reaction that were less than or equal to two in number. The other two trials did not report adverse effects [26, 28].

\section{Subgroup analyses}

The findings of the subgroup analysis by health status demonstrated that the systemic melatonin adjunctive to NSPT group showed a significant difference in PD compared with the NSPT alone group with respect to patients with comorbidities (WMD, $-1.01 ; 95 \% \mathrm{Cl},-1.61$ to $\left.-0.35 ; \mathrm{I}^{2}=72 \%\right)$ and systemically healthy patients (WMD, $-0.77 ; 95 \% \mathrm{Cl},-1.91$ to $\left.-0.36 ; \mathrm{I}^{2}=88 \%\right)(\mathrm{Fig} .5)$. However, high degrees of heterogeneity were observed between studies.

We also performed a subgroup analysis by follow-up period for CAL and found that melatonin supplementation after NSPT resulted in significantly less CAL at the 2- (WMD, -1.18; 95\% Cl, -1.56 to -0.80), 3- (WMD, - $0.83 ; 95 \% \mathrm{Cl},-1.23$ to -0.43), and 6month (WMD, $-0.94 ; 95 \% \mathrm{Cl},-1.38$ to -0.51 ) visits than NSPT alone (Fig. 6). The subgroup analysis for CAL showed a low heterogeneity.

\section{Discussion}

Due to its antioxidant and anti-inflammatory properties, and modulatory effects on bone formation, periodontal practitioners have begun to consider the use of melatonin supplementation as an adjunctive therapeutic option with NSPT in the treatment of periodontitis [4]. However, some previous publications have reported that the effects of systemic melatonin on clinical periodontal parameters are controversial in patients with periodontitis [25-28]. This meta-analysis demonstrated that the use 
of systemic melatonin + NSPT showed modest additional benefits in reducing PD by $1.12 \mathrm{~mm}$ and in decreasing CAL by 1.02 $\mathrm{mm}$ compared to NSPT + a placebo or alone. The findings of the subgroup analysis also suggested stronger treatment effects of PD reduction in shorter follow-up periods than in longer follow-up periods when adjunctive systemic melatonin was used. It is worth noting that melatonin has a wide safety margin, but systemic melatonin may have some side effects, such as sleepiness and headache $[25,27]$. Thus, when using systemic melatonin, periodontal clinicians should consider its potentially undesired side effects.

PD reduction and CAL gain are often considered clinical indicators of the successful treatment of periodontitis [31]. This systematic review and meta-analysis demonstrated that, compared with NSPT alone, the use of systemic melatonin + NSPT significantly reduced PD and CAL. Over the years, studies have demonstrated that the biological mechanisms of melatonin on the ability of periodontal healing could be attributed to the following. First, the intrinsic anti-inflammatory and antioxidant properties of melatonin can promote the early healing of periodontal tissue [32]. Studies have shown that melatonin can reduce highly destructive free radicals and oxygen and nitrogen reactive substances that cause oxidative damage to periodontal tissues, increase the antioxidant capacity of the host and depress pro-inflammatory cytokine production [21, 33], thus reducing the adverse effects of the host's immune system on periodontal tissues. On the other hand, melatonin plays an important role in regulating bone tissue formation and bone loss. Melatonin can effectively suppress the receptor activator of the nuclear factorkappa B ligand/osteoprotegerin (RANKL/OPG) signalling pathway, which is activated by osteoclast receptors, potentially suppressing the progression of alveolar bone loss [34]. Melatonin can promote osteoblastic differentiation and stimulate the synthesis of new bone matrix [24], which is manifested in the improvement of new attachment generation. Additionally, melatonin exerts a direct antimicrobial effect on some periodontal cariogenic bacteria, potentially reducing the inflammatory response of periodontal tissue [35]. These mechanisms provide possible evidence for the potential therapeutic effect of melatonin on the healing of periodontal soft and hard tissues in patients with periodontitis.

In the present study, the overall meta-analysis showed considerable heterogeneity across studies $\left(P D, I^{2}=76.0 \%\right)$. The observed heterogeneity may also be attributed to differences in the participants' characteristics, health statues, severity and range of periodontal disease, the dose and duration of melatonin, treatment conditions of NSPT, and follow-up periods among studies. First, we performed subgroup analyses of PD according to different follow-up times and health statuses. The health status subgroup analysis showed that patients with comorbidities and systemically healthy patients showed significant heterogeneity, and the follow-up time subgroup analysis suggested low heterogeneity at three months and moderate heterogeneity at six months. The follow-up time subgroup analysis showed that the heterogeneity in our study was acceptable according to the follow-up time. Therefore, the reason for the high heterogeneity may be that the follow-up time might account for more heterogeneity than the health status. Second, as for treatment conditions, Tinto and colleagues [25] carried out SRP in onesession in the full mouth under local anaesthesia and it took nearly 45 minutes per quadrant, while the investigators of three studies [26-28] did not mention the detailed treatment modality of SRP. In addition, El-Sharkawy [27] and Tinto [25] used a $0.12 \%$ and $0.20 \%$ chlorhexidine rinse in both melatonin and placebo groups after SRP, respectively, but the remaining two studies $[26,28]$ did not take any local antimicrobials after surgery. We also noted that the dose of melatonin ranged from 1 to $10 \mathrm{mg} /$ day and the duration of melatonin supplementation of included studies varied from 4 weeks to 2 months. However, due to the paucity of studies, which provided limited information, we could not perform subgroup analyses of other potentially confounding factors. Further scientific RCTs are needed to provide additional information regarding the use of melatonin in the treatment of periodontitis.

This investigation is the first systematic review and meta-analysis to determine the effects of systemic melatonin + NSPT compared to NSPT alone on clinical outcomes in patients with periodontitis. All the included studies were randomized, paralleldesigned trials, and all of them were published in the last three years. We considered three included studies to have a low risk of bias and one study to have a moderate risk of bias. For analysis purposes, we performed subgroup analyses according to follow-up periods and health status. However, some of the limitations of our research should be recognized. Melatonin is a novel host modulatory agent for use in periodontal diseases, so the number of clinical studies is relatively small. We included only four RCTs and consequently we could not assess the publications by funnel plots. 


\section{Conclusion}

The present meta-analysis shows that systemic melatonin as an adjunct to NSPT can moderately reduce PD and improve CAL in patients with CP. The use of systemic melatonin may improve the efficacy of NSPT for the treatment of CP and thereby promote improved capacity for periodontal healing. Considering the limitations of our study, it is recommended to conduct good quality RCTs with a large sample size to assess the safety and efficacy of oral melatonin. Based on data of future clinical trials, systemic melatonin might be used as a reliable adjunctive therapy for chronic periodontitis in patients.

\section{Abbreviations}

NSPT: Nonsurgical periodontal therapy; PD: Probing depth; CAL: Clinical attachment loss; WMD: Weighted mean difference; Cl:

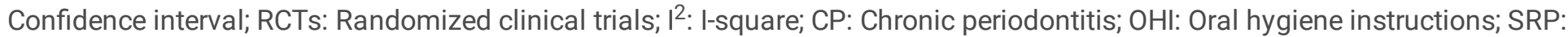
Scaling and root planning; PRISMA: Transparent Reporting of Systematic Reviews and Meta-analyses; CENTRAL: The Cochrane Central Register of Controlled Trials; WMDs: Weighted mean differences; DM: Diabetes mellitus; RANKL/OPG: Receptor activator of the nuclear factor-kappa B ligand/osteoprotegerin.

\section{Declarations}

\section{Ethics approval and consent to participate}

Not applicable.

\section{Availability of data and materials}

The data supporting the findings are available in the databases PubMed, EMBASE and CENTRAL.

\section{Consent to publish}

Not applicable.

\section{Conflict of interest}

The authors declare no conflict of interest.

\section{Acknowledgements}

Not applicable

\section{Funding}

This study was supported by the Program for Innovation Team Building at Institutions of Higher Education in Chongqing in 2016 (CXTDG201602006) and Chongqing medical research project (2015msxm055).

\section{Authors' contributions}

Yuexiang Zhen and Hui Yue searched the literature and selected the studies. Meilin Zhao and Yuexiang Zhen extracted the data. Qin Liu and Yiting Xiao assessed the quality of the included studies. Qin Liu and Hui Yue analysed the data. Yuexiang Zhen, Meilin Zhao, Hui Yue, Qin Liu and Yiting Xiao drafted the article. Yuexiang Zhen and Meilin Zhao designed the study, interpreted the data, and revised the article. All authors approved the submission.

\section{References}

1. Holtfreter B, Albandar JM, Dietrich T, Dye BA, Eaton KA, Eke PI, Papapanou PN, Kocher T: Standards for reporting chronic periodontitis prevalence and severity in epidemiologic studies: Proposed standards from the Joint EU/USA Periodontal 
Epidemiology Working Group. Journal of clinical periodontology 2015, 42(5):407-412.

2. Kinane DF, Stathopoulou PG, Papapanou PN: Periodontal diseases. Nature reviews Disease primers 2017, 3:17038.

3. Lamont RJ, Koo H, Hajishengallis G: The oral microbiota: dynamic communities and host interactions. Nature reviews Microbiology 2018, 16(12):745-759.

4. Permuy M, López-Peña M, González-Cantalapiedra A, Muñoz F: Melatonin: A review of its potential functions and effects on dental diseases. International journal of molecular sciences 2017, 18(4).

5. Armitage GC, Robertson PB: The biology, prevention, diagnosis and treatment of periodontal diseases: scientific advances in the United States. Journal of the American Dental Association (1939) 2009, 140 Suppl 1:36s-43s.

6. Cobb CM: Clinical significance of non-surgical periodontal therapy: an evidence-based perspective of scaling and root planing. Journal of clinical periodontology 2002, 29 Suppl 2:6-16.

7. Salvi GE, Lang NP: Host response modulation in the management of periodontal diseases. Journal of clinical periodontology 2005, 32 Suppl 6:108-129.

8. Donos N, Calciolari E, Brusselaers N, Goldoni M, Bostanci N, Belibasakis GN: The adjunctive use of host modulators in nonsurgical periodontal therapy. A systematic review of randomized, placebo-controlled clinical studies. Journal of clinical periodontology 2019.

9. Preshaw PM: Host modulation therapy with anti-inflammatory agents. Periodontology 2000 2018, 76(1):131-149.

10. Golub LM, Elburki MS, Walker C, Ryan M, Sorsa T, Tenenbaum H, Goldberg M, Wolff M, Gu Y: Non-antibacterial tetracycline formulations: host-modulators in the treatment of periodontitis and relevant systemic diseases. International dental journal 2016, 66(3):127-135.

11. Gugliandolo E, Fusco R, D'Amico R, Militi A, Oteri G, Wallace JL, Di Paola R, Cuzzocrea S: Anti-inflammatory effect of ATB352, a H2S-releasing ketoprofen derivative, on lipopolysaccharide-induced periodontitis in rats. Pharmacological research 2018, 132:220-231.

12. Lane N, Armitage GC, Loomer P, Hsieh S, Majumdar S, Wang HY, Jeffcoat M, Munoz T: Bisphosphonate therapy improves the outcome of conventional periodontal treatment: results of a 12-month, randomized, placebo-controlled study. Journal of periodontology 2005, 76(7):1113-1122.

13. Rocha M, Nava LE, Vazquez de la Torre C, Sanchez-Marin F, Garay-Sevilla ME, Malacara JM: Clinical and radiological improvement of periodontal disease in patients with type 2 diabetes mellitus treated with alendronate: a randomized, placebo-controlled trial. Journal of periodontology 2001, 72(2):204-209.

14. Moreno Villagrana AP, Gomez Clavel JF: Antimicrobial or subantimicrobial antibiotic therapy as an adjunct to the nonsurgical periodontal treatment: a meta-analysis. ISRN dentistry 2012, 2012:581207.

15. Krayer JW, Leite RS, Kirkwood KL: Non-surgical chemotherapeutic treatment strategies for the management of periodontal diseases. Dental clinics of North America 2010, 54(1):13-33.

16. Hardeland R, Pandi-Perumal SR, Cardinali DP: Melatonin. The international journal of biochemistry \& cell biology 2006 , 38(3):313-316.

17. Redman J, Armstrong S, Ng KT: Free-running activity rhythms in the rat: entrainment by melatonin. Science (New York, NY) 1983, 219(4588):1089-1091.

18. Cutando A, Galindo P, Gomez-Moreno G, Arana C, Bolanos J, Acuna-Castroviejo D, Wang HL: Relationship between salivary melatonin and severity of periodontal disease. Journal of periodontology 2006, 77(9):1533-1538.

19. Almughrabi OM, Marzouk KM, Hasanato RM, Shafik SS: Melatonin levels in periodontal health and disease. Journal of periodontal research 2013, 48(3):315-321.

20. Gomez-Moreno G, Cutando-Soriano A, Arana C, Galindo P, Bolanos J, Acuna-Castroviejo D, Wang HL: Melatonin expression in periodontal disease. Journal of periodontal research 2007, 42(6):536-540.

21. Hardeland R: Aging, Melatonin, and the Pro- and Anti-Inflammatory Networks. International journal of molecular sciences $2019,20(5)$. 
22. Bonnefont-Rousselot D, Collin F, Jore D, Gardes-Albert M: Reaction mechanism of melatonin oxidation by reactive oxygen species in vitro. Journal of pineal research 2011, 50(3):328-335.

23. Reiter RJ, Mayo JC, Tan DX, Sainz RM, Alatorre-Jimenez M, Qin L: Melatonin as an antioxidant: under promises but over delivers. Journal of pineal research 2016, 61(3):253-278.

24. Maria S, Witt-Enderby PA: Melatonin effects on bone: potential use for the prevention and treatment for osteopenia, osteoporosis, and periodontal disease and for use in bone-grafting procedures. Journal of pineal research 2014, 56(2):115125.

25. Tinto M, Sartori M, Pizzi I, Verga A, Longoni S: Melatonin as host modulating agent supporting nonsurgical periodontal therapy in patients affected by untreated severe periodontitis: A preliminary randomized, triple-blind, placebo-controlled study. Journal of periodontal research 2019.

26. Bazyar H, Gholinezhad H, Moradi L, Salehi P, Abadi F, Ravanbakhsh M, Zare Javid A: The effects of melatonin supplementation in adjunct with non-surgical periodontal therapy on periodontal status, serum melatonin and inflammatory markers in type 2 diabetes mellitus patients with chronic periodontitis: a double-blind, placebo-controlled trial. Inflammopharmacology 2019, 27(1):67-76.

27. El-Sharkawy H, Elmeadawy S, Elshinnawi U, Anees M: Is dietary melatonin supplementation a viable adjunctive therapy for chronic periodontitis?-A randomized controlled clinical trial. Journal of periodontal research 2019, 54(2):190-197.

28. Chitsazi M, Faramarzie M, Sadighi M, Shirmohammadi A, Hashemzadeh A: Effects of adjective use of melatonin and vitamin $\mathrm{C}$ in the treatment of chronic periodontitis: A randomized clinical trial. Journal of dental research, dental clinics, dental prospects 2017, 11(4):236-240.

29. Moher D, Liberati A, Tetzlaff J, Altman DG: Preferred reporting items for systematic reviews and meta-analyses: the PRISMA statement. BMJ (Clinical research ed) 2009, 339:b2535.

30. Higgins JPT GS, eds.: Cochrane Handbook for Systematic Reviews of Interventions Version 5.1.0. The Cochrane Collaboration $₫ 2011$. wwwcochrane-handbookorg.

31. Liu S, Hu B, Zhang Y, Li W, Song J: Minimally Invasive Surgery Combined with Regenerative Biomaterials in Treating IntraBony Defects: A Meta-Analysis. PloS one 2016, 11(1):e0147001.

32. Renn TY, Huang YK, Feng SW, Wang HW, Lee WF, Lin CT, Burnouf T, Chen LY, Kao PF, Chang HM: Prophylactic supplement with melatonin successfully suppresses the pathogenesis of periodontitis through normalizing RANKL/OPG ratio and depressing the TLR4/MyD88 signaling pathway. Journal of pineal research 2018, 64(3).

33. Vilar A, de Lemos L, Patraca I, Martinez N, Folch J, Junyent F, Verdaguer E, Pallas M, Auladell C, Camins A: Melatonin suppresses nitric oxide production in glial cultures by pro-inflammatory cytokines through p38 MAPK inhibition. Free radical research 2014, 48(2):119-128.

34. Virto L, Cano P, Jimenez-Ortega V, Fernandez-Mateos P, Gonzalez J, Haugen HJ, Esquifino Al, Sanz M: Melatonin as adjunctive therapy in the treatment of periodontitis associated with obesity. Journal of clinical periodontology 2018 , 45(11):1336-1346.

35. Srinath R, Acharya AB, Thakur SL: Salivary and gingival crevicular fluid melatonin in periodontal health and disease. Journal of periodontology 2010, 81(2):277-283.

\section{Figures}




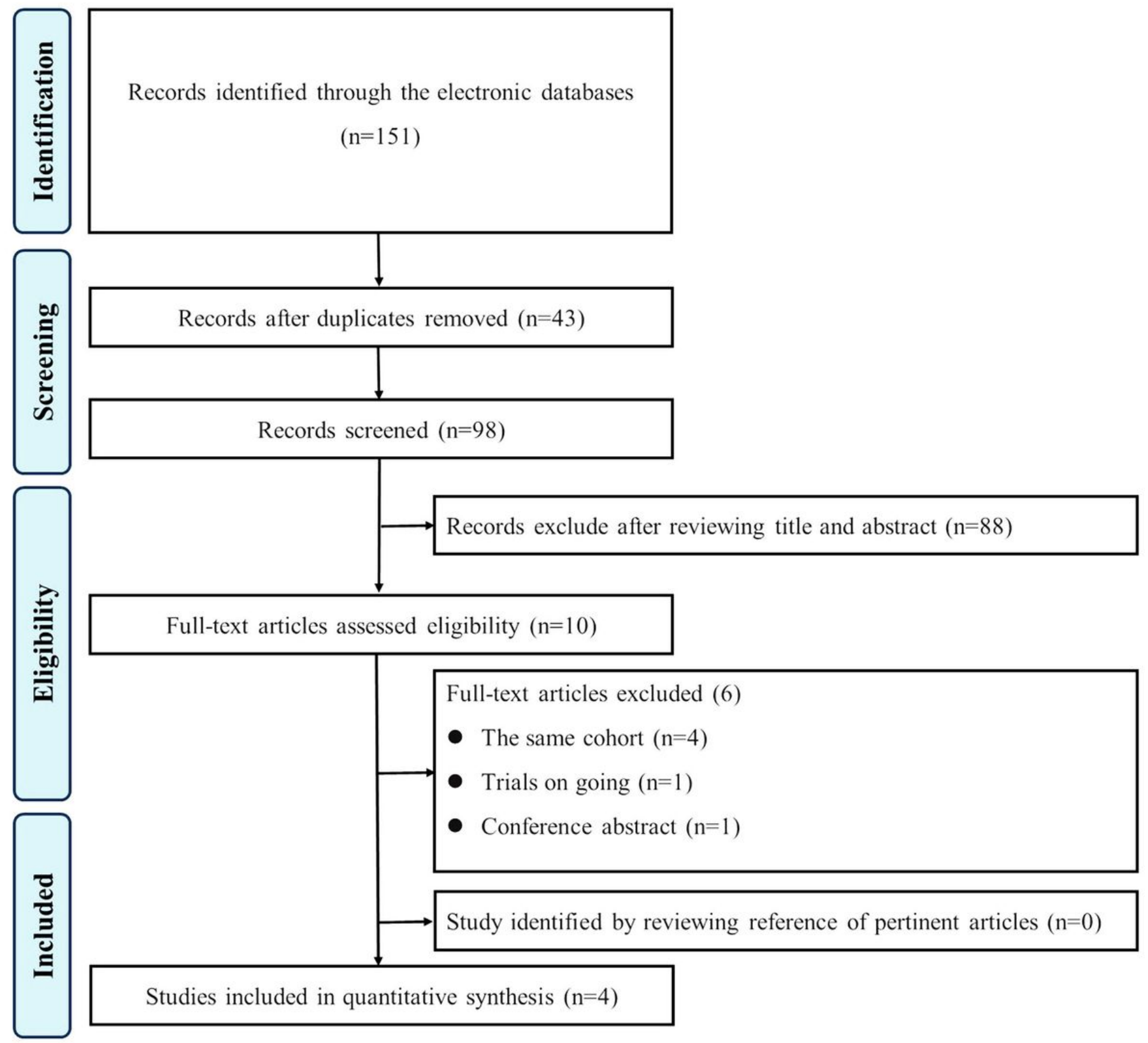

Figure 1

Flow diagram of the study selection process.

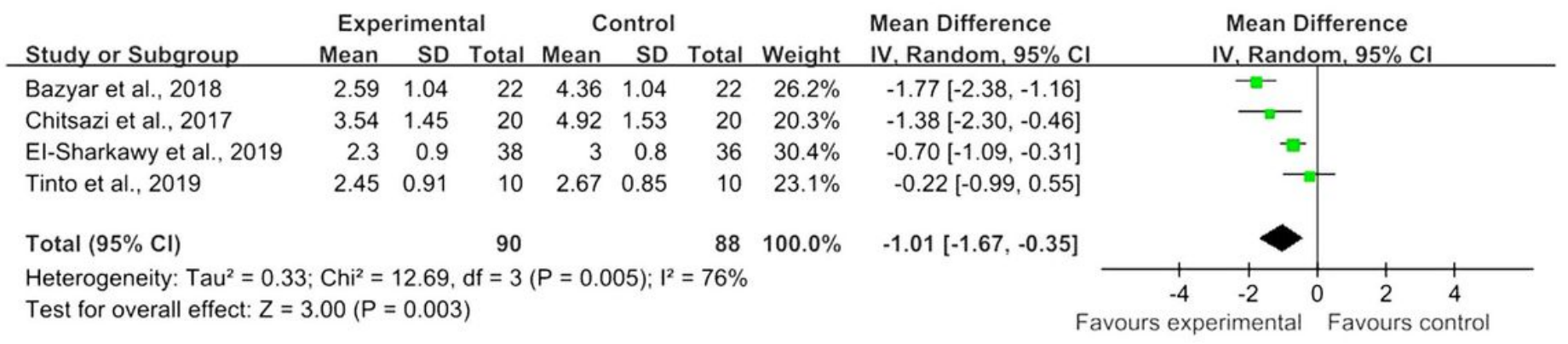

Figure 2 
Forest plot presenting overall WMDs of post-therapy on probing depth by comparing melatonin + NSPT vs. NSPT.

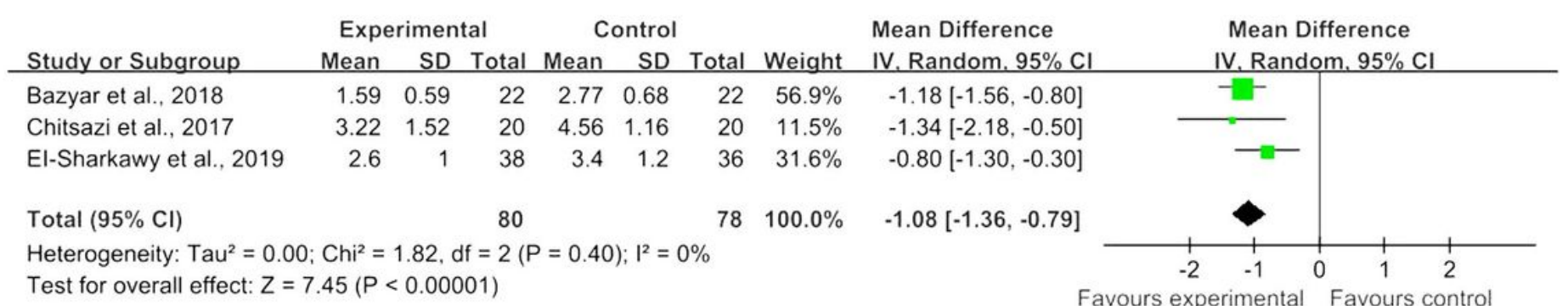

\section{Figure 3}

Forest plot presenting overall WMDs of post-therapy on clinical attachment loss by comparing melatonin + NSPT vs. NSPT.

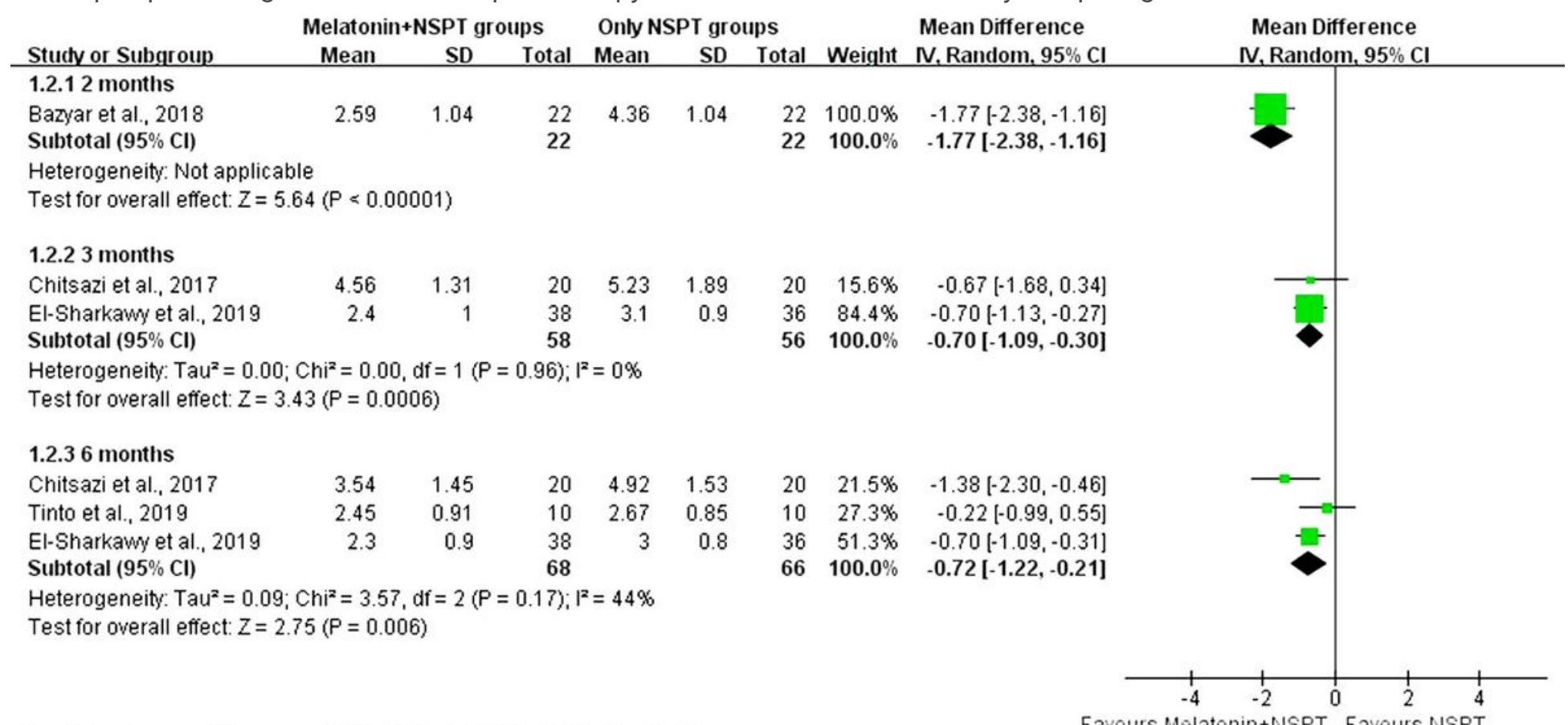

Test for subaroun differences: $\mathrm{Chi}^{2}=9.19 . \mathrm{df}=2(\mathrm{P}=0.01) . \mathrm{I}^{2}=78.2 \%$

Favours Melatonin+NSPT Favours NSPT

\section{Figure 4}

The subgroup analysis presenting the WMDs of post-therapy on probing depth by comparing melatonin + NSPT vs. NSPT only groups at 2-, 3- and 6-month follow-ups. 


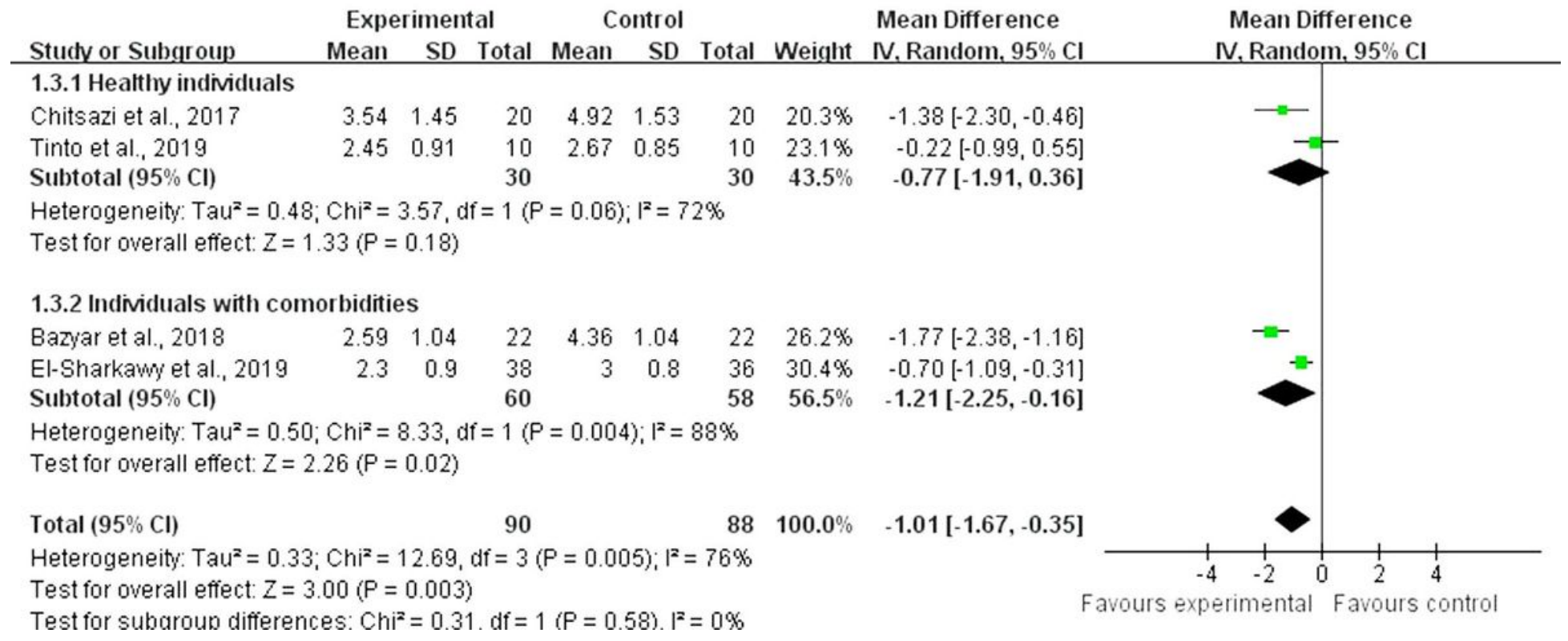

\section{Figure 5}

The subgroup analysis presenting the difference of post-therapy on clinical attachment loss by comparing melatonin + NSPT vs. NSPT only groups at 2-, 3- and 6-month follow-ups.

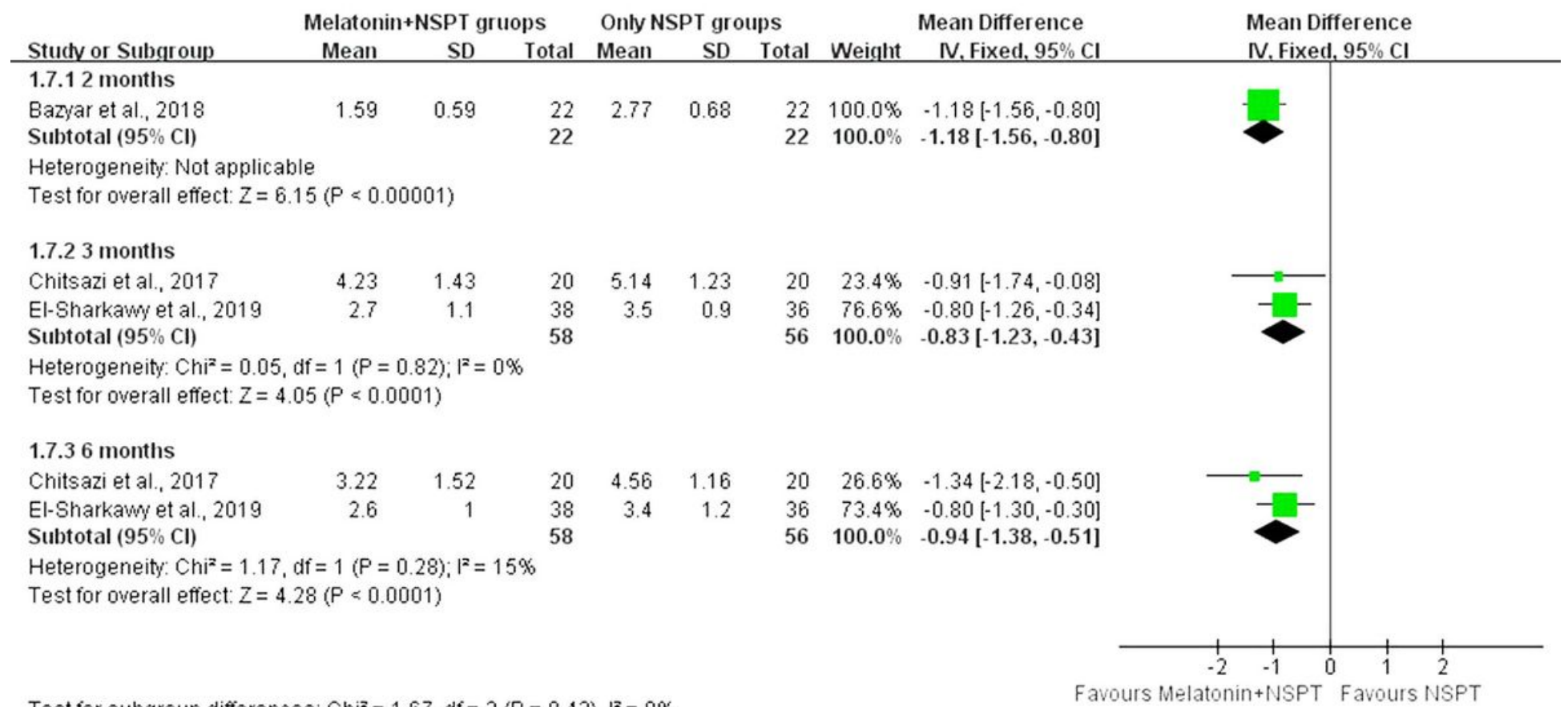

Test for subaroun differences: $\mathrm{Chi}^{2}=1.67 . \mathrm{df}=2(\mathrm{P}=0.43) \cdot \mathrm{I}^{2}=0 \%$

\section{Figure 6}

The subgroup analysis presenting the WMDs of post-therapy on probing depth by comparing melatonin + NSPT vs. NSPT only groups according health statuses.

\section{Supplementary Files}

This is a list of supplementary files associated with this preprint. Click to download.

- TableS1.docx 
- Tables2.docx

Page 15/15 